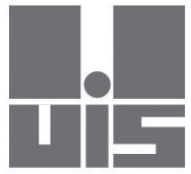

\title{
Palaeomagnetic research on karst sediments in Slovenia
}

\author{
Nadja Zupan Hajna ${ }^{1}$, Andrej Mihevc ${ }^{1}$, Petr Pruner ${ }^{2}$, Pavel Bosák ${ }^{2,1}$
}

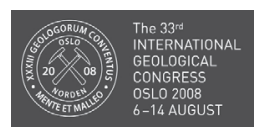

Paper presented during the GSM-03 Symposium "Karst as a global phenomenon - a tribute to Derek Ford and Paul Williams" at the 33rd International Geological Congress held at Oslo, August 6-14th 2008

\begin{abstract}
:
Zupan Hajna N., Mihevc A., Pruner P., Bosák P. 2010. Palaeomagnetic research on karst sediments in Slovenia. International Journal of Speleology, 39(2), 47-60. Bologna (Italy). ISSN 0392-6672.

We have conducted palaeomagnetic and magnetostratigraphic research on karst sediments in Slovenia since 1997. More than 2,000 samples were taken and analysed in 36 different profiles at 21 locations in caves and on the surface. Standard palaeomagnetic analyses were used (thermal and alternating field demagnetisation, magnetic susceptibility measurements, etc.). There is no evidence of younger marine deposition than Eocene in the SW part of Slovenia. Younger sediments occur only in caves and very rarely on the karst surface (different soils and a few remains of terrigeneous sediments). Marine and terrestrial Tertiary to Plio-Quaternary deposition occurs in the SE and E Slovenia. Chronostratigraphy of cave sediments in SW Slovenia completed by Rado Gospodarič in the 1980s was based on Pleistocene warm/cold cycles. Later Th/U dating indicated that speleothems from different caves in Slovenia are older. New dating principally results from palaeomagnetism and magnetostratigraphy of cave sediments calibrated, in some sites, by Th/ $U$, palaentological and geomorphological analyses. Calibrated data contributed to the reconstruction of speleogenesis, deposition in caves, and indirectly to the evolution of karst surfaces and succession of tectonic movements. The evolution of caves in the Slovenian territory took part within one post-Eocene karstification period. This period continues to the present, and can be subdivided into individual, but not well limited, phases related to Cenozoic palaeogeographical changes. The period contains distinct phases of massive deposition in caves with as yet still preserved sediments dated to about 5.4-4.1 Ma (Miocene-Pliocene), 3.6-1.8 Ma (Pliocene) and Quaternary, following the cessation of Miocene deposition in the Pannonian Basin in the central, E and SE Slovenia and post-Messinian evolution in the SW and W Slovenia.
\end{abstract}

Keywords: Magnetostratigraphy, dating, cave sediments, Dinaric Karst, Alpine Karst, Isolated Karst, karst periods, karst phases

Received 6 April 2009; Revised 29 July 2009; Accepted 2 September 2009

\section{INTRODUCTION}

Slovenia is situated in central Europe within the junction of four principal geographical regions belonging to two orographic systems (the Alps and the Dinaric Mountains) and two basins (the Pannonian and Mediterranean Basins). Karst in Slovenia has developed on carbonate rocks which cover about $43 \%$ of its total surface. According to the general morphological and hydrological conditions, three principal karst areas (Fig. 1) can be distinguished: extensive Alpine (Julijan Alps and Kamnik-Savinja Alps) and Dinaric karsts (Dinaric Mountains), and Isolated Karst (separated patches of small karst areas surrounded by nonkarst). The Slovene Dinaric region of Kras (Karst) is also known as Classical Karst, where investigations of hydrology and caves started some 150 years ago. At the moment there are more than 9,400 caves which are entered in the Cave Register of the Karst Research Institute (IZRK) ZRC SAZU in

1 Karst Research Institute, ZRC SAZU, Titov trg 2, 6230

Postojna, Slovenia

2 Institute of Geology AS CR, v. v. i., Rozvojová 269, 16500

Praha 6, Czech Republic
Postojna, and the Speleological Association of Slovenia (JZS); these data were used during our work.

Principal karst regions belong to the Southern Alps (Julian Alps, etc.) and External Dinarides (part of the Dinaric Mountain). They function as two totally different morphological units, both with different geology and relief evolution. This review of regional geology and geologic evolution is summarized mainly from Buser (1989), Vrabec \& Fodor (2006), Placer (1999, 2007) and Pirc (2007).

The SW part of Slovenia (External Dinarides) is characterised by the lack of both marine and terrestrial deposits younger than Eocene on the surface, except for different soils and a few remains of sediments in karst depressions (i.e. poljes). The last marine deposition took part here during the Eocene, when a thick pile of flysch siliciclastics was deposited. Jurassic to Paleocene limestones were exposed on the surface during the Oligocene to early Miocene within complicated nappe / overthrust structures. The area is dissected by prominent NW-SE-trending fault zones of Dinaric direction. The Oligocene/Lower Miocene to Quaternary period represented one terrestrial period with prevailing surface denudation and erosional processes. Therefore, only karst sediments found on 


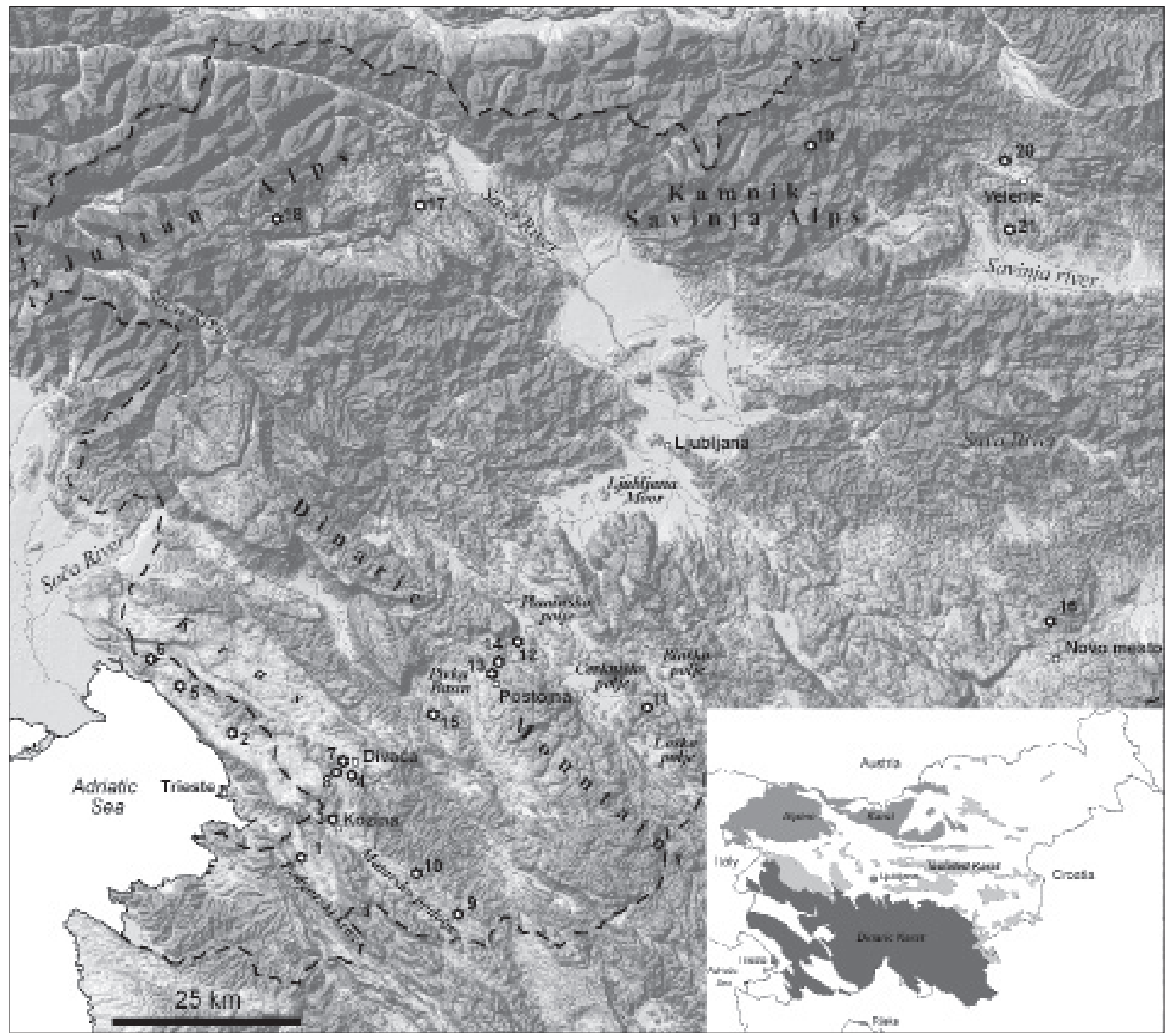

Fig. 1. Location of studied sites in Slovenia and Italy. Dinaric Karst sites: Kras Plateau and surrounding area (1- Črnotiče profiles, 2 - Briščiki, 3 - Kozina profile, 4 - Divača profile, 5 - Jama pod Kalom, 6 - Grofova jama, 7 - Divaška jama, 8 - Trhlovca, 9 - Račiška pečina, 10 - Pečina v Borštu), Notranjski kras (11 - Križna jama, 12 - Planinska jama, 13 - Postojnska jama, 14 - Zguba jama, 15 - Markov spodmol), Dolenjski kras (16 - Hrastje profile), Alpine Karst sites: Julian Alps (17 - Jama pod Babjim zobom, 18 - Jama nad Planino jezero), Kamnik-Savinja Alps (19 - Snežna jama), non-karst sediments (20 - Velenje profile) and Isolated Karst: Ponikovski kras (21 - Tajna jama). Map source: DMV 25, Geodetska uprava Republike Slovenije.

the karst surface and in the subsurface preserve the record of karst evolution and its age. Pannonian Basin and marginal (intermontane tectonic) depressions with Tertiary and Plio-Quaternary fills cover substantial parts of the SE and E parts of Slovenia (belonging both to Southern Alps and External Dinarides). Triassic to Cretaceous carbonate rocks of the Southern Alps were deformed into nappes during Eocene-Middle Oligocene, forming mostly W-Etrending structural pattern. Strong Cenozoic tectonic activity and rotations in both regional geological units affected the accelerated geomorphological evolution and karst processes - especially speleogenesis (Zupan Hajna et al., 2008a).

The research in the present paper covered all the principal karst regions, from lowlands to high mountains. The sites were located in the Dinaric Karst
(32), Julian Alps (2), Isolated Karst of the pre-Alps (1) and Plio-Quaternary fluvial sediments from the tectonic Velenje Basin (1). The low number of non-Dinaric locations is due to the lack of suitable karst sediments there. Sites included both well-known and documented deposits, as well as relatively unknown or newly found locations in caves and on the surface. Karst sediments represent an important source of information on the evolution of tectonic and geomorphological units of different sizes. The territory of Slovenia, with its karst regions, long history of karst evolution, and relatively complete knowledge of the karst sediments, represents an ideal testing ground for comprehensive research on individual infilling processes, their stages and periods. The aim of the research was focused on the time span of karst evolution, age of karst surfaces and speleogenesis, and rates of processes. 
The first systematic studies of cave sediments in Slovenia were carried out during the archaeological excavations of sediments in the entrance parts of some caves (Brodar, 1966). More extensive and detailed study of cave sediments was performed by Gospodarič $(1976,1981,1988)$. He compared cave sediments from different sites and he used different numerical and other dating methods (Franke \& Geyh, 1971; Ikeya et al., 1983; Ford \& Gospodarič, 1989) to establish the age of deposits and to distinguish different deposition phases in the subsurface. In the Kras, he linked the karstification of the area with glacioeustatic oscillations of the Adriatic Sea and the global palaeoclimate changes during the Pleistocene. He suspected that the cave sediments were not much older than $350 \mathrm{ka}$.

A better understanding of cave sediments, their age and the chronological sequence of speleologenetic events was achieved by more concentrated dating by the method (Zupan, 1991; Zupan Hajna, 1996; Mihevc \& Lauritzen, 1997; Mihevc, 2001a). Data showed that speleothem growth corresponds to warmer periods during the Pleistocene. Nevertheless there are large numbers of speleothems older than the limit of the dating method.

The study of cave deposits (Fig. 2) in Alpine caves and in unroofed caves of the Kras (Mihevc \& Zupan Hajna, 1996; Mihevc, 2001a) provided entirely new insights into the age of karst sediments and introduced new ideas concerning the development of karst and caves.

The application and interpretation of palaeomagnetic analyses and magnetostratigraphy of cave sediments, both clastic and chemogenic, which began on the Kras in 1997, suggested substantial changes of time span in which deposition took part in caves (e.g., Bosák et al., 1998, 1999, 2000, 2004; Šebela \& Sasowsky 1999, 2000; Audra, 2000; Mihevc et al. 2002; Zupan Hajna et al. 2008a, b). Magnetostratigraphy data and the arrangement of obtained magnetozones often indicated ages of the cave fill from 1.77 Ma up to over $5 \mathrm{Ma}$.

\section{METHODS}

The present paper summarizes our results from the period of 1997 to 2008; full details are available elsewhere (Zupan Hajna et al., 2008a). Our palaeomagnetic research included a total of 21 sites (19 in Slovenia and 2 in Italy) with 36 profiles; all except one were cave or karst surface sediments. During the last ten years we did complex research of karst sediments applying a number of geologic methods: palaeomagnetism and magnetostratigraphy, stratigraphy (numerical and correlated dating methods including, palaeontology - fauna, pollen), sedimentology, and mineralogy (X-ray diffraction). Palaeomagnetic studies conducted in caves have been applied to determine the age of sediments (principally fine-grained deposits - fine-grained sands, silts, clays - and speleothems) based on magnetic polarity (magnetostratigraphy) and/or palaeo-secular variations, and on palaeoenvironmental applications of mass-specific magnetic susceptibility (MS).
Palaeomagnetic analyses were completed in the Laboratory of Palaeomagnetism, IG AS CR, v. v. i. in Praha-Průhonice. Procedures were selected to allow the separation of respective components of the remanent magnetization (RM) and the determination of their geological origin. Oriented hand samples from consolidated rocks and speleothems were cut into cubes of $20 \times 20 \times 20 \mathrm{~mm}$ and subjected to alternating field demagnetization (AF) and/or thermal demagnetization (TD). Samples from unconsolidated sediments were demagnetized only by AF.

The laboratory procedures yielded results about (see Zupan Hajna et al., 2008a): mean palaeomagnetic directions, directions of C-components (with normal and reverse polarity), mean palaeomagnetic values and standard deviations $\left(J_{n}, k_{n}\right)$. Basic magnetic and palaeomagnetic properties were compiled in the logs.

Dating of cave sediments by the application of the palaeomagnetic method is a difficult and sometimes risky task, as the method is comparative in its principles and does not provide numerical ages. There exist two principal rules to obtain data for reliable interpretations: (1) to apply only dense sampling in the field (high-resolution approach with sampling distance of 2-4 cm; Zupan Hajna et al., 2008a), and (2) to apply both complete step and/or field procedures offered by both demagnetization methods; the application of complete analysis only to pilot samples and shortened, selected field/step approach, to other samples did not offer sufficient data set (Bosák et al., 2003). Correlation of the magnetostratigraphic results we obtained, and the interpretations tentatively placed upon them, has shown that in the majority of cases, application of an additional dating method is needed to either reinforce the palaeomagnetic data or to help to match them with the geomagnetic polarity timescale.

\section{RESULTS}

Cave deposits (both clastic and chemogenic) provide a record of processes (Ford \& Williams, 2007) and evidence which has not been preserved on the surface in most of karst regions of Slovenia. They can help to decipher the younger geological and tectonic history. About 2,000 samples have been sampled and processed by standard palaeomagnetic analyses, and biostratigraphic dating, mineralogical, petrological and geochemical analyses, etc. Palaeomagnetic and magnetostratigraphy studies, combined with other dating and analytical methods, offer a surprisingly new time frame for cave depositional processes they showed that most of analyzed sediments can be up to several millions of years old; which is in accordance to the idea of Sasowsky (2007).

Sites with dated cave and surface karst sediments are presented on Figure 1. Sites were located along the Dinaric Karst (Kras Plateau and surrounding area, Notranjski kras and Dolenjski kras). There were also samples from 3 sites in the Alpine Karst, one from Isolated Karst, and for comparison of the results, one from non-karst area. 


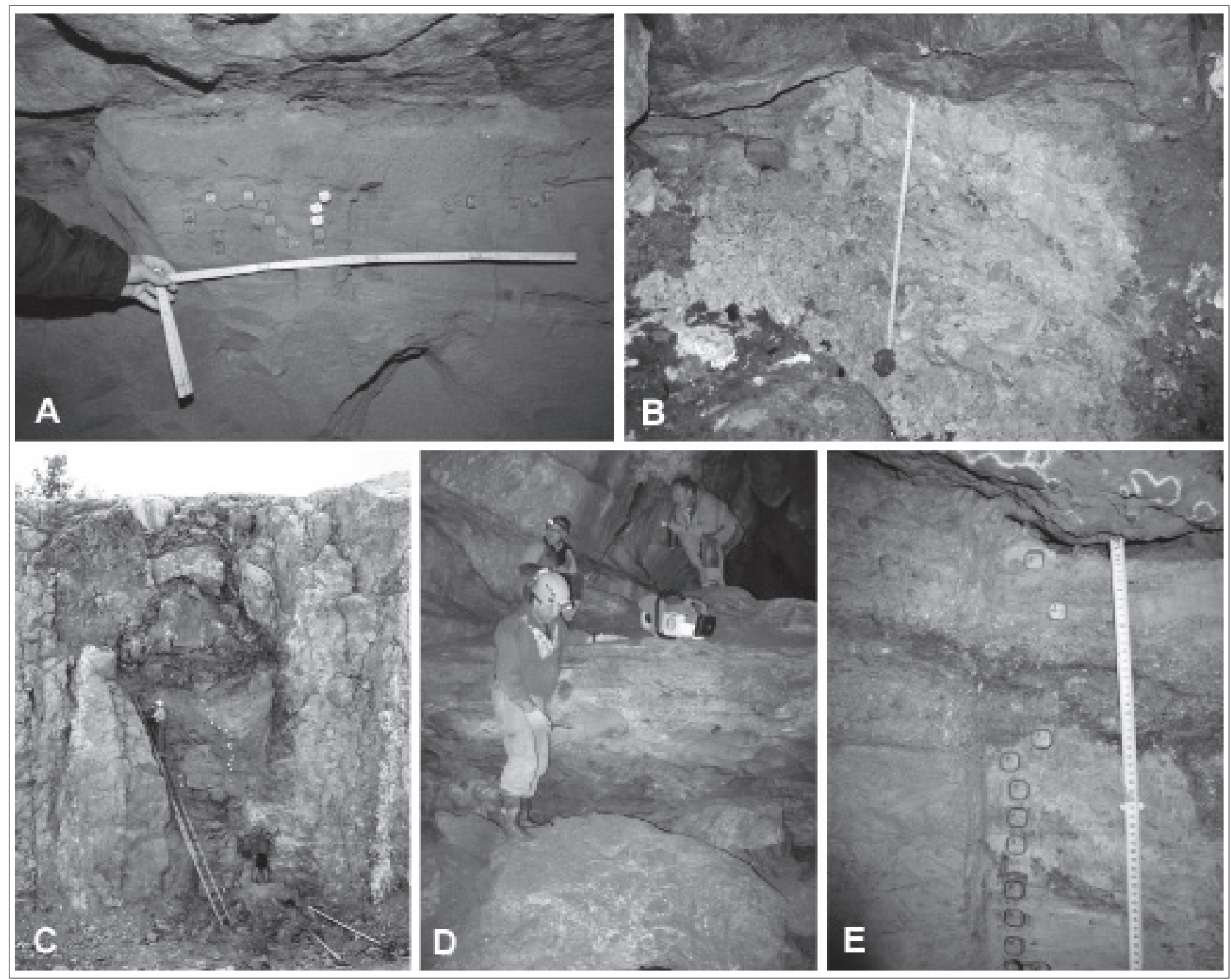

Fig. 2. Examples of sampled sites. (A): Postojnska jama Cave system - part of Umetni tunnel I profile in which the oldest fluvial deposits in the system were found; (B): Profile I in Grofova jama - bottom part with yellow montmorillonite clays; (C): Črnotiče II profile - unroofed cave filled by yellow fluvial sediments covered by red clay with flowstone, sampling points are located by paper cards; (D): Profile of flowstone layers in Trhlovca Cave, below this profile, also fluvial sediments were sampled; $(E)$ : Sampling with plastic boxes in unconsolidated sediments; example from Tajna jama.

\section{Kras Plateau}

The Kras is a low NW-SE-trending limestone plateau lying at the northernmost part of the Adriatic Sea, known also as the Classical Karst (Kras). According to its geological and geomorphological properties is divided into several smaller units. Cave sediments were studied from the Divaški kras, Nabrežinski kras, Kozinski kras, etc.

The Divaški kras (Fig. 3) covers the SE part of the Kras Plateau around Divača village. The evolution of this karst is well demonstrated in caves at different altitudes. On the surface at $400-440 \mathrm{~m}$ a. s. 1., there are numerous unroofed caves, proved by massive flowstone, and allogenic cave sediments, the largest of them is $1.8 \mathrm{~km}$ long. Other caves are at different depth; some of them like Divaška jama and Trhlovca Cave are shallow. The deepest is Škocjanske jame cave system with $18 \mathrm{~km}$ of known cave passages at $317-156 \mathrm{~m}$ a. s. 1 . The sampling started at sites of Divaški kras: Divača profile, Divaška jama and Trhlovca Cave (Bosák et al., 1998). The results were exceptionally good, even when obtained in rather primitive conditions. They indicated that the cave fills are substantially older than initially expected. This fact was not in accordance with the previous karstological models in Slovenia, but illustrated and proved the new ideas and data obtained by numerical dating, the discovery of unroofed caves and their dating by geomorphic means (Mihevc, 1996). Nevertheless, the interpretation of the magnetostratigraphic picture was problematic, as there were no palaeontological finds.

The Divača profile represented a nearly unroofed cave with a partly disintegrated roof. The cave was completely filled by fluvial deposits. The profile was older than $1.77 \mathrm{Ma}$, i.e. the top of the Olduvai subchron. The geometry of the magnetozones could indicate an age as great as about 5.23 Ma (base of normal /N/ polarized Thvera subchron within the Gilbert Chron). The substantial age of the cave is supported by the thin roof, indicating significant thickness reduction of limestone roof by chemical denudation.

Divaška jama and Trhlovca (Fig. 2D) are situated in the SW part of the levelled surface of the Divaški 


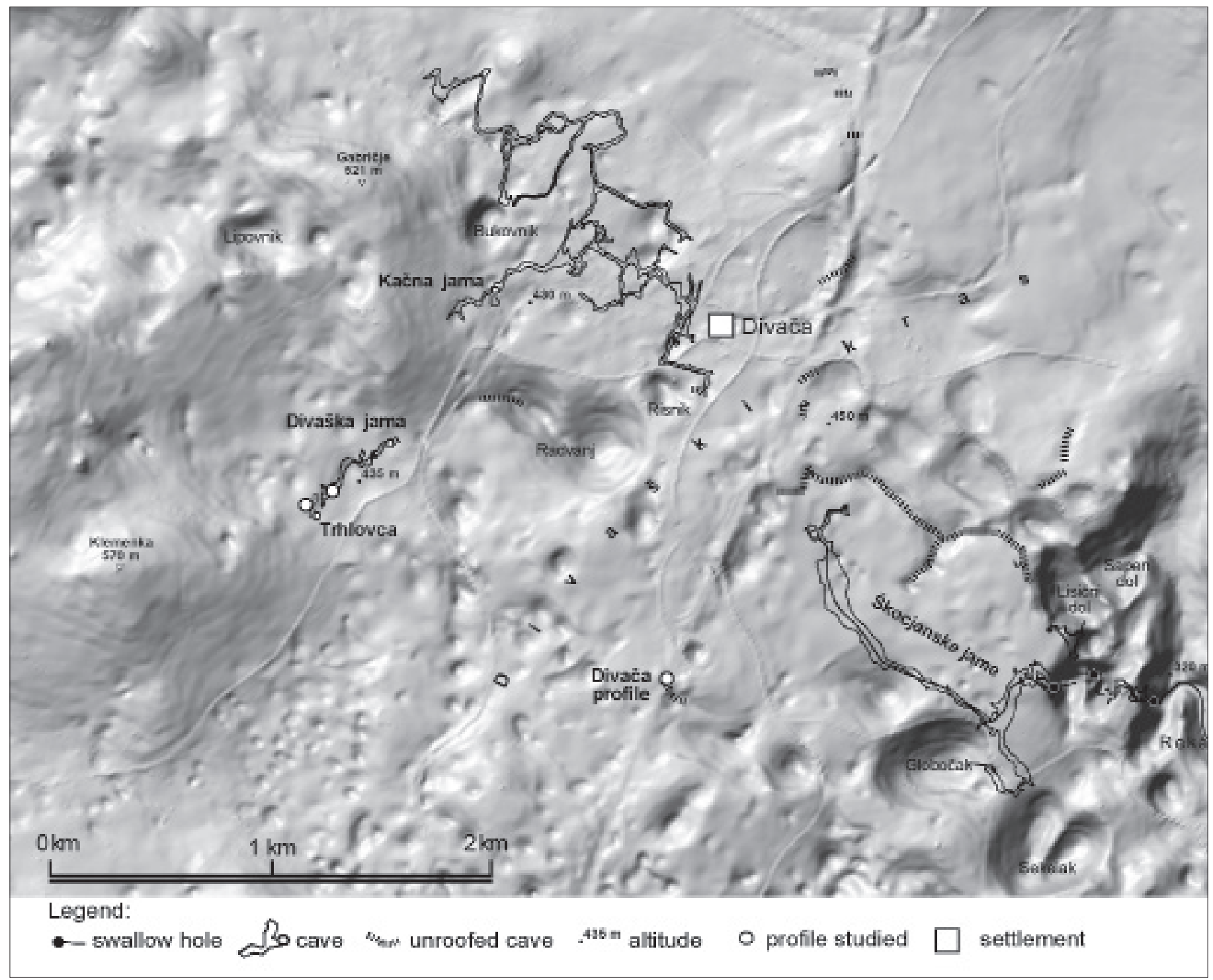

Fig. 3. Shaded relief digital terrain model of Divaški kras with deep collapse dolines, ground plans of: Divaška jama, Kačna jama, Škocjanske jame, and marked locations of studied sites: Divača profile, Trhlovca and Divaška jama. DEM data source: DMV 25, Geodetska uprava Republike Slovenije and Cave Register of IZRK ZRC SAZU and JZS. Notice: well expressed linear features of the surface belongs to traffic lines.

kras. Numerous dolines occur on the surface above the cave, but they are not directly connected to it. The caves represent an approximately $700 \mathrm{~m}$ long relict of an originally larger cave system formed at about 350 to $410 \mathrm{~m}$ a. s. 1 . In both caves there exists a lot of speleothem from different times and the remains of fluvial deposits. The laminated sediments from Trhlovca were attributed to the Günz (Gospodarič, 1981, 1988). The fill of Divaška jama represents one of the clear examples of temporary interruption of speleogenetic and cave-forming processes. Based on our initial results (Bosák et al., 1998), the sediments were dated around the Jaramillo N polarity subchron within the Matuyama reverse (R) epoch. Highresolution re-sampling of the whole profile changed this interpretation. The arrangement of $\mathrm{R}$ and $\mathrm{N}$ polarized magnetozones (Fig. 4) is clearly older than 1.77 Ma (Zupan Hajna et al., 2008a). Both caves underwent a prolonged and complicated evolution. It cannot be excluded that Trhlovca represents an old fragment of a completely choked cave that was later rejuvenated as the consequence of the evolution of Divaška jama and its fill. It is also possible that the cave sediments from Trhlovca and Divaška jama may represent the equivalent of the fill of Divača and Kozina profiles (unroofed caves; for details see Bosák et al., 1998; 2000).

Grofova jama is a cave situated just below the top (275 m a. s. 1.) of one of several small hills at the NW edge of Kras Plateau, about $150 \mathrm{~m}$ above its levelled surface. The hill may represent either tectonically uplifted block or residual erosional high (Zupan Hajna et al., 2008a). According to the morphology of walls and passages, the cave was formed in phreatic conditions. At one stage the cave was completely filled with K-rich montmorillonitic (beidellite) clay when it was situated at a much lower relative altitude. The sediment was later partly washed out and covered with red terra rossa-like clay, but still with high montmorillonite content. In the sampled profile (Fig. 2B) we obtained N and $\mathrm{R}$ polarities, and segments without any magnetic signal (Zupan Hajna et al., 2008a). The character and composition of cave fill clearly indicate that pure beidellite clays represent in situ weathering products 


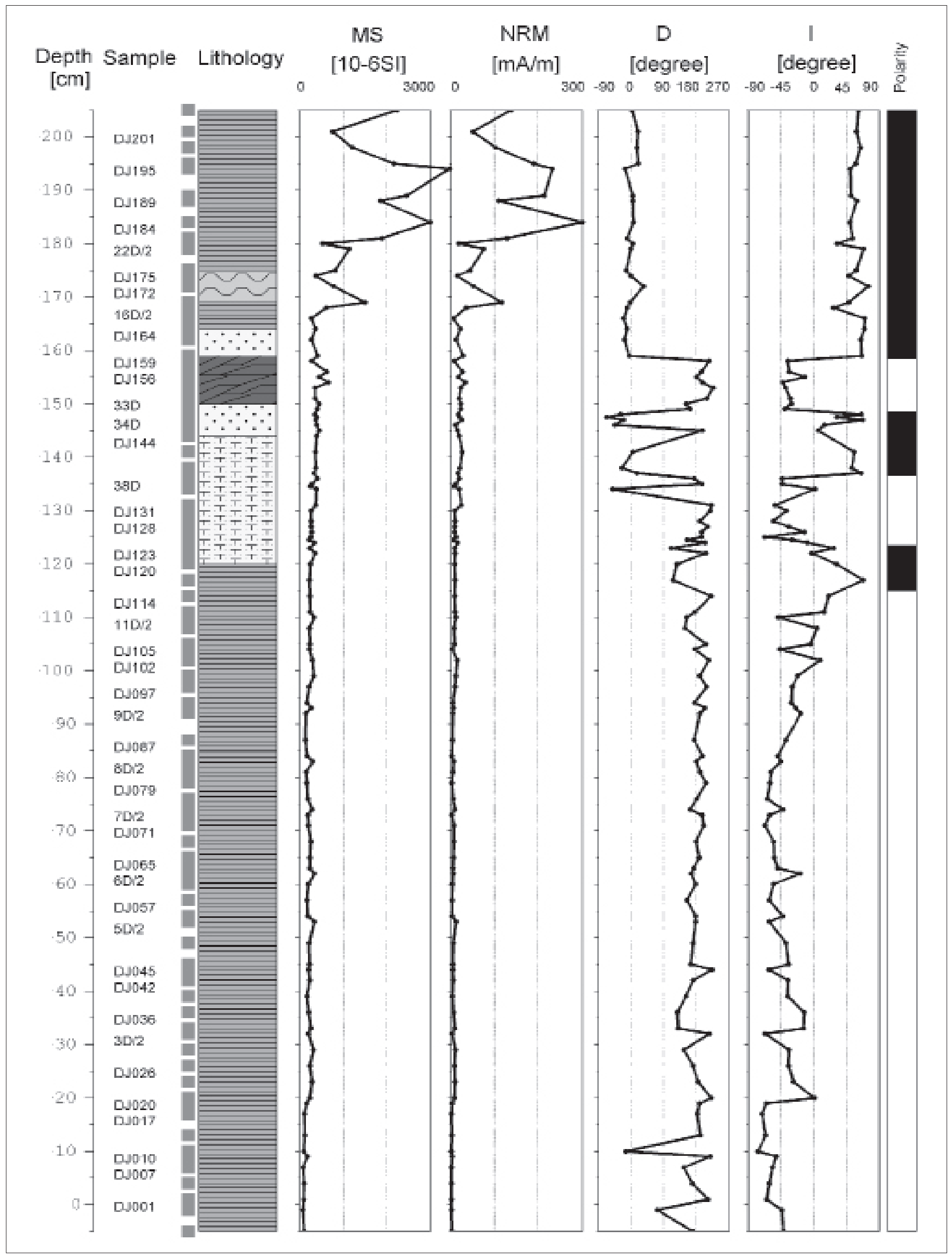

Fig. 4. Basic magnetic and palaeomagnetic properties of Divaška jama profile. Legend: Lithology: straight lines in grey - siltyclay, dots - sand, waves in light grey - flowstone, $\mathrm{T}$ with dots - calcareous silt, boxes in dark grey - collapse structure; Polarity scale: black - normal polarized magnetozones, white - reverse polarized magnetozones, grey - mixed polarity; MS - magnetic susceptibility; NRM - natural remanent magnetization; D - declination; I - inclination. 
of volcaniclastic material in humid and warm climates of the tropical type, and volcaniclastic material was relatively pure and fine-grained deposited in quite thick pile over bedrock. The source of volcanic ash should be found in some of Oligo-Miocene volcanic centres around the Mediterranean, like Colli Euganei and Marostica Hills (north Italy, 170 and $160 \mathrm{~km}$ to the W) or the Smrekovec (north Slovenia, now about 100 $\mathrm{km}$ to the E). Therefore, we can anticipate relatively great age of the fill (up to $35 \mathrm{Ma}$ ).

\section{Podgorski kras and Matarsko podolje}

The Podgorski kras is about $5 \mathrm{~km}$ wide and up to $15 \mathrm{~km}$ in length, a karst plateau between Slavnik Mountain (1025 m a. s. 1.) on the NE and littoral hills on the SW. The plateau is separated from the Kras on the NW by an important tectonic line with a drop of about $50 \mathrm{~m}$. Two profiles of cave sediments were studied in Črnotiče Quarry.

The Matarsko podolje is a $20 \mathrm{~km}$ long and $2-5 \mathrm{~km}$ wide flat valley-like karst surface. The surface is dissected by a number of dolines. The longitudinal section shows that the surface gently rises from about $490 \mathrm{~m}$ a. s. 1. at Kozina village (in the NW) to $650 \mathrm{~m}$ a. s. 1. on the SE end. Cave sediments from Račiška pečina and Pečina v Borštu were studied.

The Crnotiče Quarry is situated on the W margin of the Podgorski kras, ca $6 \mathrm{~km}$ to the $\mathrm{SE}$ from the Adriatic coast. The quarry is carved in the leveled surface at $440 \mathrm{~m}$ a. s. 1. Numerous caves have been opened during quarry operations. Most of them were completely filled by sediments. We sampled two profiles (Črnotiče I and Črnotiče II). The Črnotiče I profile was composed of banded carbonates (cave stromatolite; Bosák et al., 1999) with intercalations of red clays (probable fish remains were not still determined), deposited over corroded/eroded surfaces of older, highly re-crystallized speleothems. The $\mathrm{N}$ and $\mathrm{R}$ polarity magnetozones were interrupted by many unconformities of unknown duration. Therefore, any correlation with the geomagnetic polarity timescales (GPTS) is problematic. Nevertheless, according to the arrangement of individual magnetozones on standard scales we can assume that the whole profile is older than the top of the Olduvai event $(1.77 \mathrm{Ma})$. The interpretation of palaeomagnetic parameters (Bosák et al., 1999, 2004) and finds of fauna at the Črnotiče II profile (Horáček et al., 2007) clearly indicated that the age of the Črnotiče I profile can easily be as great as $4.2-5.2 \mathrm{Ma}$.

About $40 \mathrm{~m}$ to the south of the Črnotiče I profile a new vertical profile in a side passage was exposed. Črnotiče II profile (Fig. $2 \mathrm{C}$ ) is about $7 \mathrm{~m}$ wide and $17 \mathrm{~m}$ high passage completely filled with sediments. Laminated and cyclically-arranged fluvial sediments composed the lower part of the fill and were covered by breccia of fragments of massive flowstone. The modern karst surface cuts across the flowstones, exposing them in the form of an unroofed cave. The site is also characterized by a rich appearance of fossil tubes of autochthonous stygobiont serpulid Marifugia cavatica. $\mathrm{U} / \mathrm{Pb}$ dating of Marifugia cavatica was not successful. The arrangement of obtained magnetozones site was originally interpreted as older than $1.77 \mathrm{Ma}$, most probably belonging to the Gauss Chron (2.581-3.58 Ma) or the normal subchrons within the Gilbert Chron (4.18-5.23 Ma; Bosák et al., 2004). Paleontological data enabled matching the magnetostratigraphic record precisely with the GPTS. The vertebrate record is composed mostly of teeth enamel fragments of rodents and soricomorphs (with Deinsdorfia sp., Beremedia fissidens, Apodemus cf. atavus, Rhagapodemus cf. frequens, Glirulus sp., Cseria sp.) is obviously quite older: suggests the Pliocene age MN15-MN16 (ca 3.0-4.1 Ma; Horáček et al., 2007). The development of vertical drawdown shafts with a predominance of later autochthonous fill resulted from vadose speleogenesis caused by the drop of karst water level related to tectonic uplift, which followed tectonic unrest during the MN 15 to MN16b mammalian biozones. The results of the sediment ages indicate the cessation of the main phase of vertical speleogenesis in the vadose zone in the area, which was connected with continuous uplift and shift of active phreatic speleogenesis to lower levels. After that, the intensive planation (Bosak et al. 2004) was active on the surface, which led to the formation of the levelled surface of the Podgorski kras and to collapse of the roofs of horizontal caves.

Račiška pečina is the best dated profile of cave sediments in Slovenia. It is located in Matarsko podolje. The cave is $304 \mathrm{~m}$ long simple southwards dipping gallery, a relict of an old cave system, which was opened by denudation to the surface. The studied sequence, $13 \mathrm{~m}$ long, of banded flowstones, is situated in the southern part of the cave; about $200 \mathrm{~m}$ from present entrance. The composite thickness of the sampled profile (Fig. 5) reaches $634 \mathrm{~cm}$, but the true thickness of exposure is only about $300 \mathrm{~cm}$. The sediments were well dated by different methods. For the first time, the magnetostratigraphic sequence was correlated satisfactorily with the GPTS by biostratigraphy (Horáček et al., 2007). Based on mammalian fauna analysis (assemblage with Apodemus, cf. Borsodia), the age was determined to middle-late MN17 (ca 1.82.4 Ma; Quaternary age is excluded). The boundary of $\mathrm{N}$ and $\mathrm{R}$ polarized magnetozone within the layer with fauna $(F)$ was identified with the bottom of Olduvai subchron (1.77-1.95 Ma). The short N chron just below the Olduvai base was correlated with the Reunion subchron (2.14-2.15 Ma) and in the lower part of the profile, the following magnetozones were correlated: the base of Matuyama Chron (2.150$2.581 \mathrm{Ma}$ ) and the individual subchrons within the dominantly normal polarized Gauss Chron (2.581$3.58 \mathrm{Ma})=$ C2An.1n subchron (2.581-3.04 Ma), Keana subchron (3.04-3.11 Ma), C2An.2n subchron (3.11-3.22 Ma), Mammoth subchron (3.22-3.30 Ma) and the upper part of C2An.3n subchron (top at 3.33 $\mathrm{Ma}$ ). The bottom flowstone layer at the NW side of the studied profile terminates at about 3.4 Ma. For the conclusion it may be emphasised that the roughly $3 \mathrm{~m}$ high profile was growing for more than $3 \mathrm{Ma}$ and that new speleothems on top are still growing. 


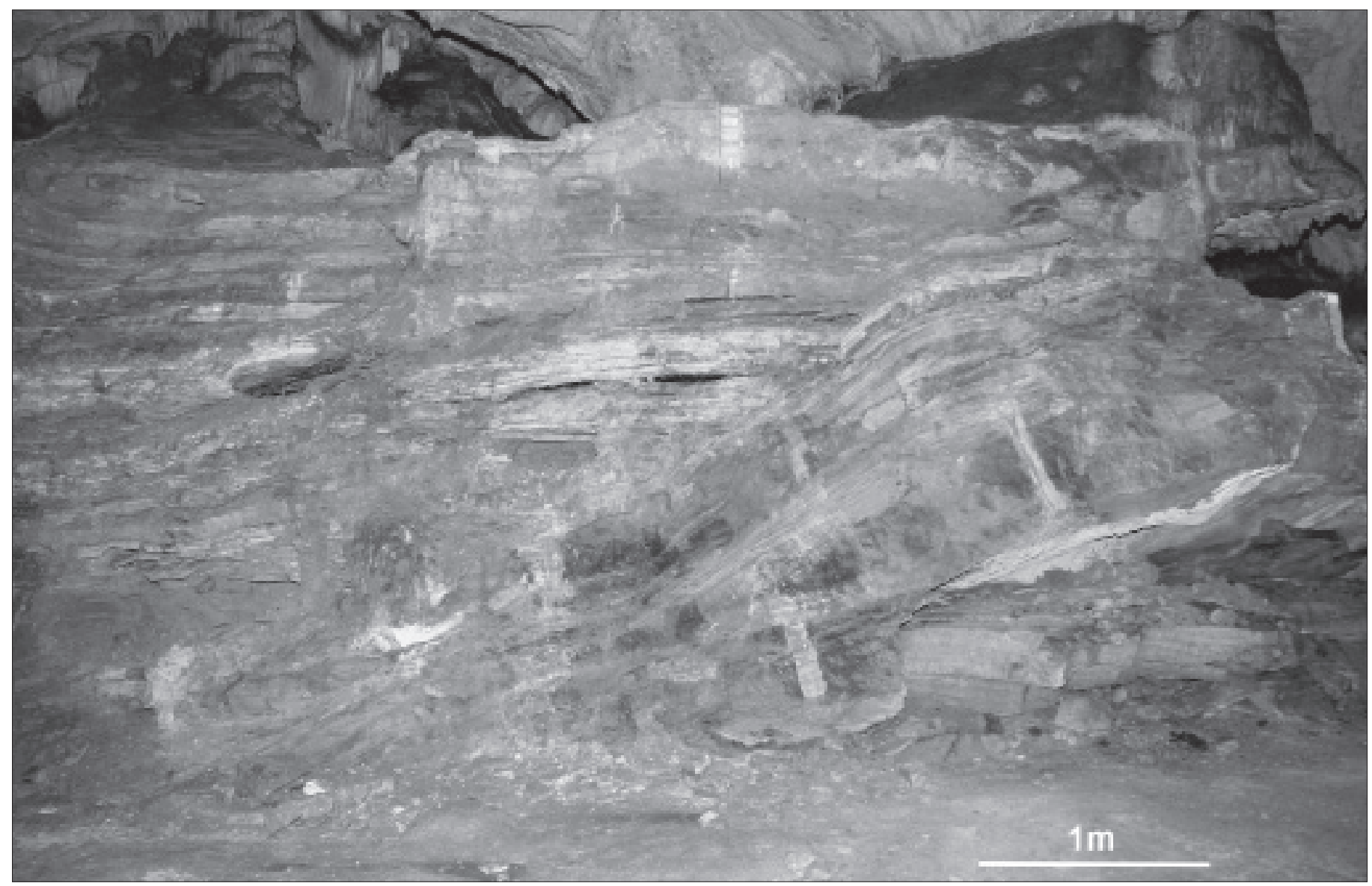

Fig. 5. Photograph of NW part of Račiška pečina profile with visible trenches, where flowstone was sampled.

Račiška pečina, Ulica pečina and the unroofed Ulica Cave represent most likely remnants of the same cave system, which was developed at the same time and at the same altitude. The cave system still retains traces of paragenetic, epiphreatic and phreatic features (large cupolas and scallops). The transition to the vadose zone caused exhumation and internal redistribution of cave fill and the growth of massive speleothems (large domes and stalagmites) on allogenic deposits. The system was later dissected by erosion and denudation into the segments with more entrances, where the cave roof was thinned or completely destroyed.

\section{Notranjski kras}

The karst of Notranjska (Inner Carniola) includes a large proportion of the central and highest parts of the Dinaric Karst, with varying geomorphic units (high-karst plateaus, planated surfaces at lower positions, small flysch basins with sinking rivers, and karst poljes). Several sites were studied in the area surrounding Postojna: Postojna cave system (8 profiles; Fig. 6), Zguba jama (2 profiles), Planinska jama (1 profile), Markov spodmol (2 profiles) and Križna jama (2 profiles).

The Postojnska jama-Planinska jama cave system and a number of smaller adjacent caves (such as Zguba jama) are developed in the karst between Postojna Basin and Planinsko polje. The caves are located between two dextral strike-slip fault zones of the Dinaric direction. Caves contain lithologically diverse sedimentary fill, ranging from speleothems to allogenic fluvial sediments. The allogenic clastic material is derived from a single source, Eocene siliciclastics of the Pivka Basin (Zupan Hajna, 1998). Detailed palaeomagnetic and magnetostratigraphy data (Zupan Hajna et al., 2008a, b) revealed greater complexity than previous magnetostratigraphic interpretations (Šebela \& Sasowsky, 1999). Three short $\mathrm{R}$ magnetozones (excursions) were detected only in a few places (Spodnji Tartarus). Within the limits of statistical error, the Spodnji Tartarus North, Pisani rov and Biospeleološka postaja profiles show declination and inclination directions close to the present. The Rudolfov rov, Spodnji Tartarus South, Umetni tunel 1, Male jame and Zguba jama profiles must be older due to slight or distinct counterclockwise rotation associated with tectonism of the Adria Microplate (Vrabec \& Fodor, 2006). We interpreted most of the sediments as being younger than $0.78 \mathrm{Ma}$, belonging to various depositional events within the Brunhes Chron. The $\mathrm{N}$ polarization in sediments of the Umetni tunnel 1 site and Zguba jama can be linked with some of $\mathrm{N}$ polarized subchrons older than $0.78 \mathrm{Ma}$. Sediments in Umetni tunnel 1 (Fig. 2A) are the oldest in the system and were not included in older stratigraphic schemes (Gospodarič, 1976, 1981, 1988). They may be correlated with Olduvai, Reunion or even older chrons (i.e. from 1.77 to over $2.15 \mathrm{Ma}$ ). The cave system has evolved over a long period of time, governed by the functioning of Planinsko polje in relation to the evolution of the resurgence area in Ljubljana Moor further to the E. General stabilization of the hydrological system with low hydraulic head led to the evolution of caves in 
POSTOJNSKA JAMA

Reg. No. 747

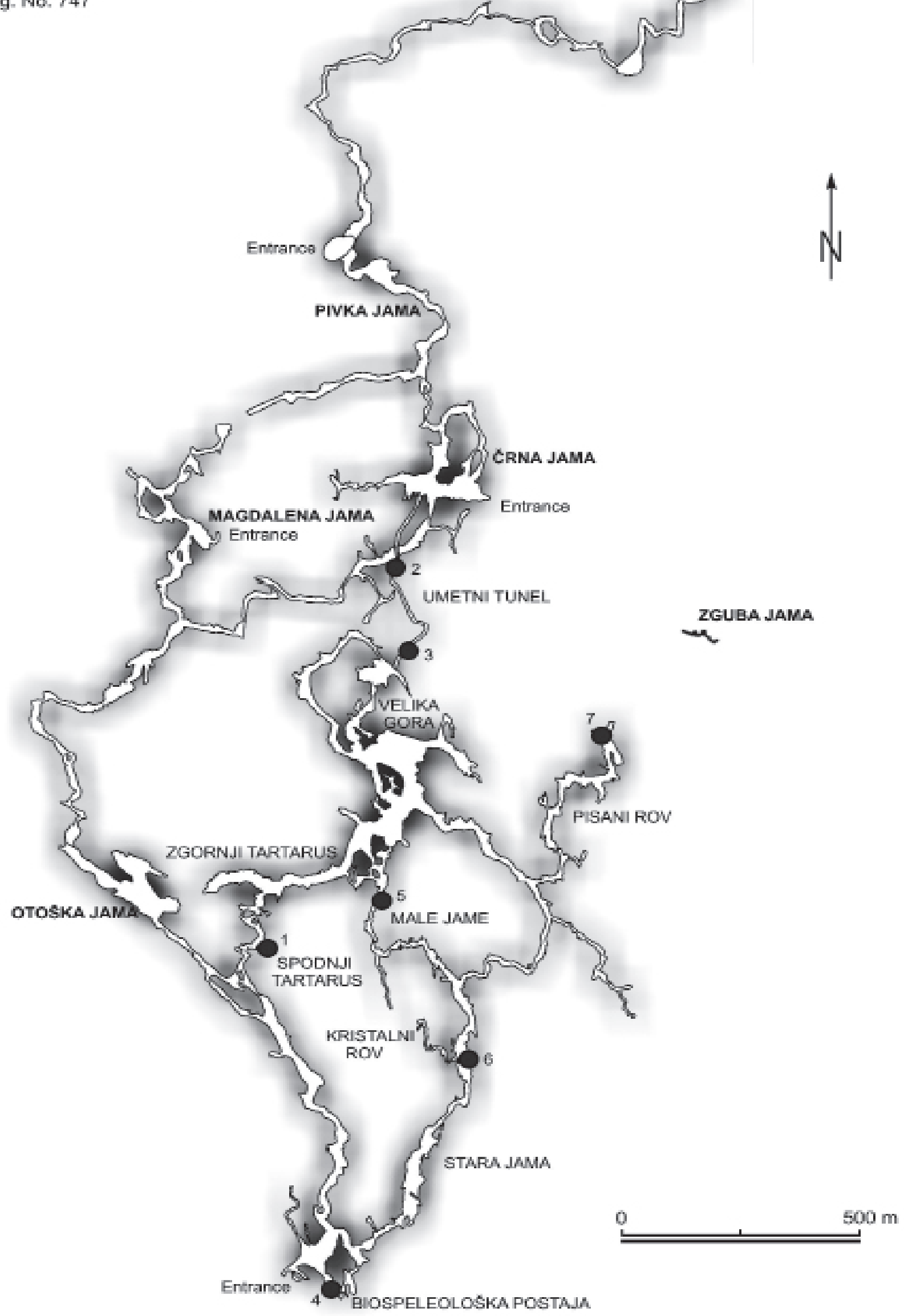

Fig. 6. Profile locations in Postojnska jama Cave system (cave map after Cave Register of the IZRK ZRC SAZU and JZS ). Legend: 1 - profiles in Spodnji Tartarus, 2 -Umetni tunnel I profile, 3 - Umetni tunnel II profile, 4 - profile in Biospeleološka postaja, 5 -Male jame profile, 6 - Stara jama profile, 7 - Pisani rov profile. 
epiphreatic and paragenetic conditions over a long time-span. Individual cave segments or passages were completely filled and exhumed several times during the evolution of the cave (Zupan Hajna et al., 2008a). Erosion and deposition were synchronous in different parts of the system. Alternation of depositional and erosional phases may be connected with changing conditions within the cave system, the functioning of the resurgence area, collapse, climatic change, tectonic movement and the intrinsic mechanisms of contact karst.

Markov spodmol is a horizontal cave about 900 $\mathrm{m}$ long and $12 \mathrm{~m}$ deep. The entrance lies on the southern edge of a blind valley opening into the Pivka Basin. The cave serves as an intermittent ponor for the small brook. The studied profile was situated in a side passage or large niche of the main passage about $150 \mathrm{~m}$ from the entrance. The section of fluvial sediments is about $4 \mathrm{~m}$ thick. The palaeomagnetic and magnetostratigraphy results we obtained showed that the profile in Markov spodmol is composed at least of three different sequences (Zupan Hajna et al., 2008a). The age of the fill can be interpreted as follows: the upper laminated clay was deposited within the normal Brunhes Chron, the multi-coloured clays and sands/gravels were deposited in Matuyama or Gauss Chrons, and the lower laminated clay is older than the middle sequence. Traces of in situ weathering in the lower part of the profile indicate a quite prolonged hiatus in deposition. The creation of a weathered zone under subsurface conditions needs prolonged time and warm/humid external climate. The weathering supports a rather higher age of the profile.

Križna jama is large river cave situated in the area between Loško, Bloško and Cerkniško poljes. Remains of fluvial sediments are preserved throughout the entire cave, indicating that it was filled by more and different sediments in the past (Gospodarič, 1974). The Medvedji rov (Bear Passage) represents one of older passages. There were studied 2 profiles where the remains of Ursus spelaeus in clay are inter-bedded among flowstone sheets. New radiometric dates (Zupan Hajna et al., 2008a) have proved the results and interpretations of Ford \& Gospodarič (1989). Remains of cave bears in two layers are definitely older than $125 \mathrm{ka}$. Paleomagnetic results (prevailing $\mathrm{N}$ polarization of the profiles) indicate an age younger than the Brunhes/Matuyama boundary at $780 \mathrm{ka}$. The thin $\mathrm{R}$ polarized magnetozone represents one of the short-lived excursions of the magnetic field within the Brunhes Chron, which is older than about 146$160 \mathrm{ka}$.

\section{Dolenjski kras}

The karst of Dolenjska (Lower Carniola) is an area of the SE of Slovenia; it is also described as the covered lowland karst of Dolenjska (Gams, 2003; Kranjc, 1990) and belongs to the Dinaric Karst. Dolines, uvalas, karst poljes and rounded hills predominate. The surface is covered with a thick layer of red karst soil. A sediment profile was taken at Profile No. 207 of highway construction in the section Hrastje-Lešnica,
$\mathrm{N}$ of Novo mesto (Zupan Hajna et al. 2008a).

Hrastje profile was composed mostly of clays and silty clays with interbeds to laminas of clayey-sandy and clayey silts. The colour of the sediments was dominantly grey, sometimes brown and beige mottled and with yellowish brown lamination. The whole profile is $\mathrm{N}$ polarized except the lowest sample, which is R (Zupan Hajna et al., 2008a). Without gastropod and plant determinations, there can be three possible interpretations of the age: the deposition took place within the Brunhes Chron $(<780 \mathrm{ka})$, or at the Brunhes/Matuyama boundary (780 ka). The $\mathrm{R}$ polarization represents an excursion within the $\mathrm{N}$ polarized magnetozone; or the profile could be older than the Brunhes Chron.

\section{Alpine Karst}

The Alps in the northern part of Slovenia form two large mountain groups: the Julian and KamnikSavinja Alps with dominant W-E orientation. The Julian Alps are deeply incised by the Soča and Sava river valleys and their tributaries. The plateaus and other surfaces are without surface waters. Karst springs appear in the bottoms of the valleys. There are numerous closed depressions, dolines and deep vadose shafts, but horizontal caves are rare (e.g., Jama pod Babjim zobom, Spodmol nad Planino Jezero). The high plateaus and valleys were glaciated during the Pleistocene. Glaciation only slightly transformed the pre-glacial karst landscape. The Kamnik-Savinja Alps are dissected by the Sava and Savinja rivers into narrow ridges and valleys. Numerous karst plateaus are found on the SE. Remnants of several horizontal caves are preserved, but deep shafts predominate. Fluvial sediments can be found in some horizontal caves, e.g., Potočka zijalka and Snežna jama na Raduhi (Mihevc, 2001b). These sediments were deposited by sinking rivers before the main valley entrenchment that followed the fast tectonic uplift of this part of Alps (Bosák et al., 2002).

The substantial age of cave fills in the area can be deduced from occurrences of cave entrances on upper slopes of deeply entrenched valleys at high altitudes: e.g., Jama pod Babjim zobom, Spodmol nad Planino Jezero and Snežna jama (Zupan Hajna et al., 2008a). The fill of caves is clearly older than $1.77 \mathrm{Ma}$. Such an old age indicates the entrenchment of rivers for more than $900 \mathrm{~m}$ which was the consequence of the tectonic uplift (Mihevc, 2001b). The change of depositional environment is well reflected by the palaeomagnetic parameters (Zupan Hajna et al., 2008a).

Speleothems in Snežna jama (Fig. 7) can be correlated with the Matuyama to Gilbert Chrons. The geometry and arrangement of individual magnetozones, taking into account also hidden time on unconformities, indicates that the most probable correlation with the GPTS offer subchrons at 3.0 to $5.0 \mathrm{Ma}$ time span; another acceptable correlation could be 1.8 to $3.6 \mathrm{Ma}$ (Bosák et al., 2002).

The evolution of karst plateaus and massifs in the Slovenian Alps is comparable with another part of the Alpine chain - the Northern Calcareous Alps - where 


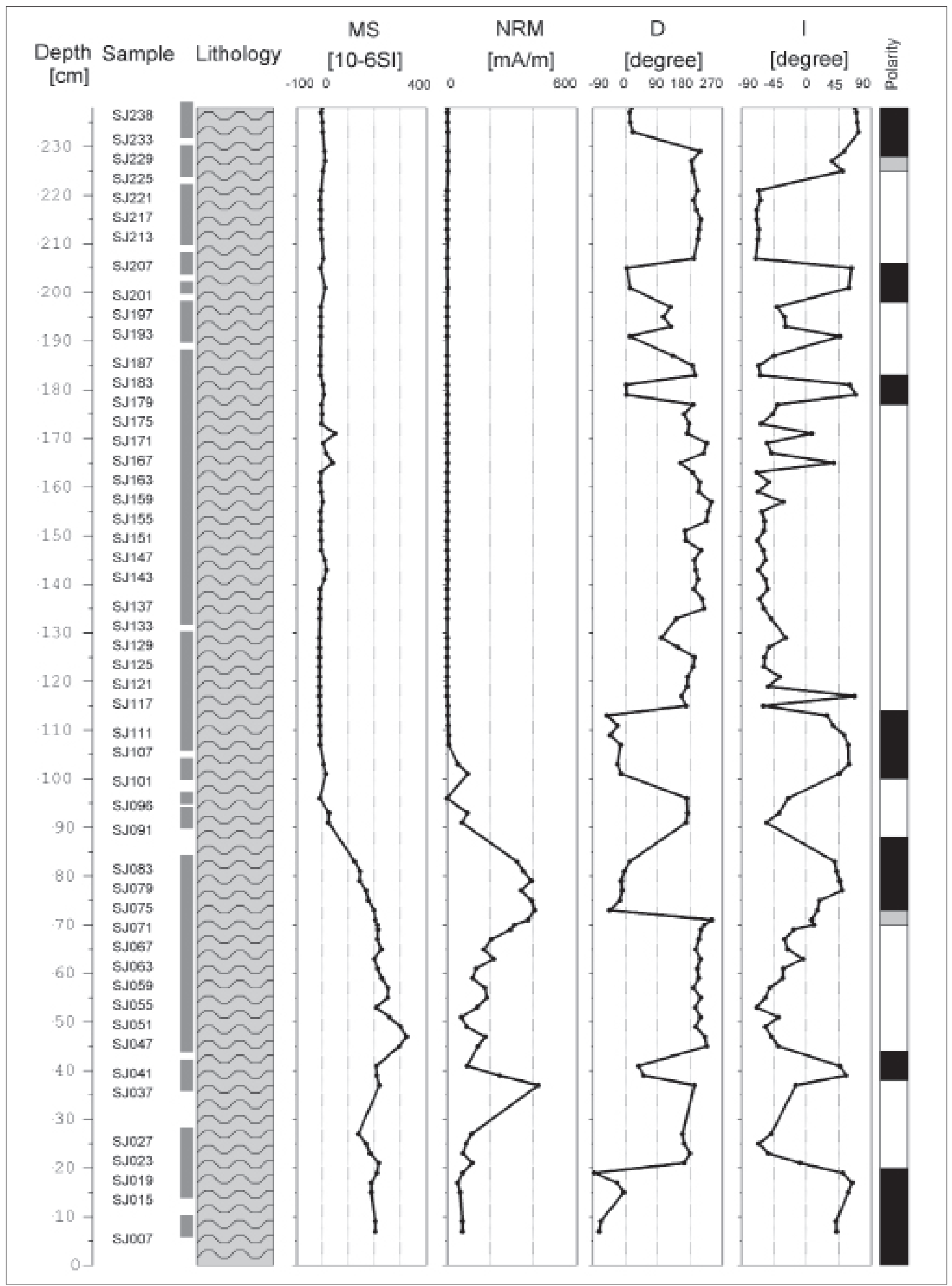

Fig. 7. Basic magnetic and palaeomagnetic properties of Snežna jama. Legend: Lithology: waves - flowstone; Polarity scale: black - normal polarized magnetozones, white - reverse polarized magnetozones, grey - mixed polarity; MS - magnetic susceptibility; NRM - natural remanent magnetization; D - declination; I - inclination. 
caves occur also from 1300 to more than $1700 \mathrm{~m}$ a. s. 1. (Zötl, 1989; Frisch et al., 2000), i.e. about 900 $\mathrm{m}$ above recent river-beds.

\section{Isolated Karst}

Small karst plateaus, ridges, dolines, blind valleys and caves are interspersed with fluvial landforms formed on non-carbonate rocks are characteristic for the Isolated Karst of the middle part of Slovenia. There are several small rivers sinking into the karst and then emerging on the other sides of ridges.

Tajna jama is situated in a small isolated karst area in the central part of Slovenia. An approximately 2 $\mathrm{m}$ high profile (Fig. 2E) of fine laminated sediments covered by disintegrated conglomerate is preserved in the upper part of the meandering canyon. An alternation of $\mathrm{N}$ and $\mathrm{R}$ magnetized zones was discovered (Zupan Hajna et al., 2008a). The most probable age interpretation dates back cave sediments to about 3.0 to 3.4 Ma, i.e. to the Gauss Chron. The erosion surface within the lower $\mathrm{R}$ magnetized zone is related also with the change of inclination. The boundary, if representing a prominent hiatus, could shift the age of the lower $\mathrm{R} / \mathrm{N}$ boundary down to $4.18 \mathrm{Ma}$ (top of the Cochiti subchron). This interpretation is supported by declination values.

\section{CONCLUSIONS}

Paleomagnetic research on cave fills in the Dinaric, Alpine and Isolated karsts has opened new horizons for the interpretation of karst and cave evolution. The data inform us that a number of common features and evolution trends exist in all studied regions. On the other hand, as the consequence of different post-Eocene tectonic regimes, there exist distinct differences in evolution of smaller geomorphic units within the more extensive ones.

The most important result concerns the age (Tab. 1 and 2) of cave fills, which are substantially older than expected from earlier research. Palaeomagnetic

Tab. 1. Ages of cave sediments interpreted from Dinaric Karst (bold numbers $=\mathrm{Th} / \mathrm{U}$ data).

\begin{tabular}{|c|c|c|c|c|}
\hline \multirow{2}{*}{ Name of site } & \multirow{2}{*}{ Name of profile } & \multicolumn{2}{|c|}{ Age (Ma) } & \multirow{2}{*}{ Age of cave fill } \\
\hline & & Min. & Max. & \\
\hline Grofova jama & & $?$ & Up to 35 & \multirow{8}{*}{ Miocene/Pliocene } \\
\hline Črnotiče & $\mathrm{I}$ & 4.2 & 5.4 & \\
\hline Briščiki & & $>1.77$ & $>5.0$ & \\
\hline Jama pod Kalom & Lower part & $>1.77$ & $>5.0$ & \\
\hline Divača profile & & $>1.77$ & $>5.23$ & \\
\hline Kozina profile & & $>1.77$ & $>5.0$ & \\
\hline Trhlovca & & $>1.77$ & $>5.0$ & \\
\hline Divaška jama & Lower part & $>1.2$ & $>5.0$ & \\
\hline Črnotiče & II Right & $1.77 ?$ & $<3.58$ & \multirow{9}{*}{$\begin{array}{c}\text { Pliocene } \\
\text { to } \\
\text { Pleistocene (Günz/Mindel) }\end{array}$} \\
\hline Črnotiče & II Main & 1.8 & 3.58 & \\
\hline Račiška pečina & & 1.77 & $>3.4$ & \\
\hline Markov spodmol & $\mathrm{I}$ & $<0.78$ & 3.58 & \\
\hline Markov spodmol & II & $>0.78$ & 3.58 & \\
\hline Postojnska jama & Umetni tunel I & $<0.99$ & $>2.15$ & \\
\hline Postojnska jama & Male jame & $?$ & $>0.78$ & \\
\hline Postojnska jama & White sandstone & $?$ & $>0.78$ & \\
\hline Zguba jama & $1+I I$ & $<0.78$ & $>0.78$ & \\
\hline Divaška jama & Upper part & 0.092 & 0.576 & \multirow{10}{*}{ Pleistocene (Mindel)/Holocene } \\
\hline Jama pod Kalom & Upper part & $<0.05$ & $<0.78$ & \\
\hline Postojnska jama & Tartarus North & $?$ & $<0.78$ & \\
\hline Postojnska jama & Tartarus South & $>0.122$ & $<0.78$ & \\
\hline Postojnska jama & Pisani rov & $>0.35$ & $<0.78$ & \\
\hline Postojnska jama & Stara jama & $?$ & $<0.78$ & \\
\hline Planinska jama & Rudolfov rov & $?$ & $<0.78$ & \\
\hline Račiška pečina & Top & $<0.09$ & $<0.78$ & \\
\hline Križna jama & $1+11$ & $\geq 0.03$ & $<0.78$ & \\
\hline Pečina v Borštu & & $>0.194$ & $<0.78$ & \\
\hline
\end{tabular}

Tab. 2. Ages of cave sediments interpreted from Alpine and Isolated karsts (bold number $=$ Th/U data).

\begin{tabular}{|c|c|c|c|}
\hline \multirow{2}{*}{ Name of site } & \multicolumn{2}{|c|}{ Age (Ma) } & \multirow[t]{2}{*}{ Age of cave fill } \\
\hline & Min. & Max. & \\
\hline Snežna jama & $>1.2$ & $>5.0$ & \multirow{4}{*}{ Miocene/Pleistocene } \\
\hline Tajna jama & \pm 0.78 & 4.18 & \\
\hline Jama pod Babjim zobom & $>0.78$ & $>1.77$ & \\
\hline Spodmol nad Planino Jezero & $>0.78$ & $?$ & \\
\hline
\end{tabular}


data in combination with other dating methods has shifted the possible beginning of speleogenesis and cave infilling processes deeply below the Tertiary/ Quaternary boundary.

For the first time in Slovenia, biostratigraphic data contributed (Horáček et al., 2007) to the correlation of magnetostratigraphy logs with the GPTS and to allocate the ages of cave fill more precisely to preQuaternary times. Palaeontological finds in the Račiška pečina and Črnotiče Quarry partly support the age interpreted from magnetostratigraphy - cave fills are often Pliocene in age and even older (Horáček et al., 2007).

The present situation in the Slovenian karst is the result of more or less steady state karstification since the (late) Oligocene. Nevertheless, this ongoing period can be subdivided into individual, but not clearly delimited, phases related to Cenozoic palaeogeographical changes, i.e. changing tectonic regimes, individual marine ingressions and regressions, cessation of deposition in the Paratethys area, evolution of tectonic basins. The period contains three distinct phases of massive deposition in caves with extant sediments dated to about 5.4-4.1 Ma (Miocene-Pliocene), 3.6-1.8 Ma (Pliocene), and Quaternary, following the cessation of Miocene deposition in Slovene part of the Pannonian Basin, and the last, but principal, change of the tectonic regime at about $6 \mathrm{Ma}$ (Vrabec \& Fodor, 2006).

\section{ACKNOWLEDGMENTS}

We acknowledge field assistance of the technical staff of the Karst Research Institute ZRC SAZU from Postojna and Institute of Geology AS CR, v. v. i. from Prague. Analyses, processing and interpretation in the Czech Republic were carried out within projects No. AV0Z30130516, IAA300130701 and MEB 090619. Research activities in Slovenia were covered by research programs of the Slovenian Research Agency Nos. P6-0119-0618 and P0-0119, and project No. J6-6345-0618-04.

\section{REFERENCES}

Audra P., 2000 - Le karst haut alpin du Kanin (Alpes juliennes, Slovénie-Italie). Etat des connaissances et données récentes sur le fonctionement actuel et l'évolution plio-quaternaire des structures karstiques. Karstologia, 35: 27-38.

Bosák P., Hercman H., Mihevc A. \& Pruner P., 2002 High resolution magnetostratigraphy of speleothems from Snežna Jama, Kamniške-Savinja Alps, Slovenia. Acta carsologica, 31/3: 15-32.

Bosák P., Knez M., Otrubová D., Pruner P., Slabe T. \& Venhodová D., 2000 - Palaeomagnetic Research of Fossil Cave in the Highway Construction at Kozina, SW Slovenia. Acta carsologica, 29/2: 15-33.

Bosák P., Mihevc A. \& Pruner P., 2004 - Geomorphological evolution of the Podgorski Karst, SW Slovenia: Contribution of magnetostratigraphic research of the Crnotiče II site with Marifugia sp. Acta carsologica, 33/1: 175-204.
Bosák P., Mihevc A., Pruner P., Melka K., Venhodová D. \& Langrová A., 1999 - Cave fill in the Crnotiče Quarry, SW Slovenia: Palaeomagnetic, mineralogical and geochemical study. Acta carsologica, 28/2: 15-39.

Bosák P., Pruner P. \& Kadlec J., 2003 Magnetostratigraphy of cave sediments: Application and limits. Studia Geophysica et Geodaetica, 47, 2: 301-330.

Bosák P., Pruner P. \& Zupan Hajna N., 1998 Paleomagnetic research of cave sediments in SW Slovenia. Acta carsologica, 27/2: 151-179.

Bosák P., Pruner P., Mihevc A. \& Zupan Hajna N., 2000 - Magnetostratigraphy and unconformities in cave sediments: case study from the Classical Karst, SW Slovenia. Geologos, 5: 13-30.

Brodar S., 1966 - Pleistocenski sedimenti in palaeolitska najdišc̆a $v$ Postojnski jami (Pleistocene sediments of Palaeolitic site in Postojna Cave). Acta carsologica, 4: 57-138.

Buser S., 1989 - Geološki razvoj Slovenije. In: Javornik M., Voglar D. \& Dermastia A. (Eds.): Enciklopedija Slovenije. 1. Mladinska knjiga, 1987-2002, 1989, 3, Eg-Hab.: 195-203.

Cande, S.C. \& Kent, D.V., 1995 - Revised calibration of the geomagnetic polarity timescale for the Late Cretaceous and Cenozoic. Journal of Geophysical Research, 100/B4: 6093-6095.

Ford D. \& Williams P., 2007 - Karst Hydrogeology and Geomorphology. Wiley, Chichester, 562 p.

Ford D.C. \& Gospodarič R., 1989 - U series dating studies of Ursus spelaeus deposits in Križna jama, Slovenia. Acta carsologica, 18: 39-51.

Franke H. \& Geyh M., 1971 - 14C - Datierungen von Kalksinter aus slowenischen Höhlen. Der Aufschluss, 22: 235-237.

Frisch W., Székely B., Kuhlemann J. \& Dunkl I., 2000 Geomorphologicaevolution of the EasternAlpsin response to Miocene tectonics. Zeitschrift für Geomorphologie, 44: 103-138.

Gams I., 2003: Kras v Sloveniji v prostoru in času. Založba ZRC, ZRC SAZU, Ljubljana, 516 p.

Gospodarič R., 1974 - Fluvialni sedimenti v Križni jami (Fluvial sediments in Križna Cave). Acta carsologica, 6: 327-366.

Gospodarič R., 1976 - Razvoj jam med Pivško kotlino in Planinskim poljem $v$ kvartarju (Evolution of caves between Pivka Basin and Planina Polje in Quaternary). Acta carsologica, 7: 5-139.

Gospodarič R., 1981 - Generations of speleothems in the Classical Karst of Slovenia. Acta carsologica, 9 (1980): 90-110.

Gospodarič R., 1988 - Paleoclimatic record of cave sediments from Postojna karst. Annales de la Société Géologique de Belgique, 111: 91-95.

Horáček I., Mihevc A., Zupan Hajna N., Pruner P. \& Bosák P., 2007 - Fossil vertebrates and paleomagnetism update one of the earlier stages of cave evolution in the Classical Karst, Slovenia: Pliocene of Črnotiče II site and Račiška pečina. Acta carsologica, 37/3: 451-466.

Ikeya M., Miki T. \& Gospodarič R., 1983 - ESR Dating of Postojna Cave Stalactite. Acta carsologica, 11(1982): 117-130. 
Kranjc A., 1990 - Dolenjski kraški svet (The Karst World of Dolenjska). Dolenjska založba, Novo mesto, 240 p.

Mihevc A. \& Lauritzen S.E., 1997 - Absolute datations of speleothems and its speleomorphological significance from Divaška jama and Jazbina caves; Kras plateau, Slovenia. Proc. 12th International Congress of Speleology, vol. 1, La Chaux-de-Fonds, Switzerland: 57-59.

Mihevc A. \& Zupan Hajna N., 1996 - Clastic sediments from dolines and caves found during the construction of the motorway near Divača, on the classical Karst. Acta carsologica, 25: 169-191.

Mihevc A., 1996 - Brezstropa jama pri Povirju (Unroofed cave at Povir). Naše jame, 38: 92-101.

Mihevc A., 2001a - Speleogeneza Divaškega krasa (Speleogenesis of the Divača Karst). Zbirka ZRC, 27, Ljubljana, $180 \mathrm{p}$.

Mihevc A., 2001b - Jamski fluvialni sedimenti v Snežni jami na Raduhi in $v$ Potočki zijalki (Cave fluvial sediments in Snežna jama na Raduhi and Potočka zijalka). Geološki zbornik, 16: 60-63, Ljubljana.

Mihevc A., Bosák P., Pruner P. \& Vokal B., 2002 - Fossil remains of the cave animal Marifugia cavatica in the unroofed cave in the Crnotiče quarry, W Slovenia. Geologija, 45/2: 471-474.

Pirc S., 2007 - Short otline of geology of Slovenia. In: Hlad B. \& Herlec U. (Eds.): Geological heritage in the South-European Europe. Field Guide, Environmental Agency of the Republic of Slovenia, Ljubljana: 5-6.

Placer L., 1999 - Contribution to the macrotectonic subdivision of the border region between Southern Alps and External Dinarides. Geologija, 41(1998): 223-255.

Placer L., 2007 - Kraški rob (landscape term); Geologic section along the motorway Kozina-Koper (Capodistria). Geologija, 50/1: 29-44.

Sasowsky I., 2007 - Clastic Sediments in Caves - Imperfect Recorders of Processes in Karst. Acta carsologica, 36/1: 143-149.
Šebela S. \& Sasowsky I., 1999 - Age and magnetism of cave sediments from Postojnska jama cave system and Planinska jama Cave, Slovenia. Acta carsologica, 28/2: 293-305"

Šebela S. \& Sasowsky I., 2000 - Paleomagnetic dating of sediments in caves opened during highway construction near Kozina, Slovenia. Acta carsologica, 29/2: 303-312.

Vrabec M. \& Fodor L., 2006 - Late Cenozoic tectonics of Slovenia: structural styles at the Northeastern corner of the Adriatic microplate. In: Pinter N., Grenerczy G., Weber J., Stein S. \& Medak D. (Eds.), The Adria microplate: GPS geodesy, tectonics and hazards, NATO Science Series, IV, Earth and Environmental Sciences, 61, Springer, Dordrecht: 151-168.

Zötl J., 1989 - Paleokarst as an important hydrogeological factor. In: Bosák P., Ford D.C., Głazek J. \& Horáček I. (Eds), Paleokarst. A systematic and regional review, Academia-Elsevier, Praha-Amsterdam: 483-509.

Zupan Hajna N., 1996 - The valuation of absolute speleothem dating from Slovenia. In: Lauritzen, S.E. (Ed.), Climate change: the Karst record: extended abstracts of a conference held at Department of geology University of Bergen, Norway, Charles Town: Karst Waters Institute, Special Publication, 2: 185-188.

Zupan Hajna N., 1998 - Mineral composition of clastic cave sediments and determination of their origin. Kras $i$ speleologia, 9(XVIII): 169-178.

Zupan Hajna, N., Mihevc A., Pruner P. \& Bosák P., 2008a - Palaeomagnetism and Magnetostratigraphy of Karst Sediments in Slovenia. Carsologica, 8, Založba ZRC, Ljubljana, 266 p.

Zupan Hajna, N., Mihevc A., Pruner P. \& Bosák P., 2008b - Cave sediments from the Postojnska-Planinska cave system (Slovenia): evidence of multiphase evolution in epiphreatic zone. Acta carsologica, 37/1: 63-86.

Zupan N., 1991 - Flowstone datations in Slovenia. Acta carsologica, 20: 187-204. 